Int. J. Dev. Biol. 59: 11-22 (2015)

doi: $10.1387 / \mathrm{ijdb} .150220 \mathrm{zz}$

\title{
What cell death does in development
}

\author{
ZAHRA ZAKERI ${ }^{1, \#, ~ C A R L O S ~ G . ~ P E N A L O Z A ~}{ }^{1,2}$, KYLE SMITH $^{1}$, YIXIA YE $^{1}$ and RICHARD A. LOCKSHIN ${ }^{1,3}$ \\ ${ }^{1}$ Queens College and Graduate Center, Department of Biology, City University of New York, NY, and \\ ${ }^{2}$ Schenectady County Community College, State University of New York, NY and ${ }^{3}$ St. John's University, NY, USA
}

\begin{abstract}
Cell death is prominent in gametogenesis and shapes and sculpts embryos. In nonmammalian embryos one sees little or no cell death prior to the maternal-zygotic transition, but, in mammalian embryos, characteristic deaths of one or two cells occur at the end of compaction and are apparently necessary for the separation of the trophoblast from the inner cell mass. Considerable sculpting of the embryo occurs by cell deaths during organogenesis, and appropriate cell numbers, especially in the CNS and in the immune system, are generated by massive overproduction of cells and selection of a few, with death of the rest. The timing, identity, and genetic control of specific cells that die have been well documented in Caenorhabditis, but in other embryos the stochastic nature of the deaths limit our ability to do more than identify the regions in which cells will die. Complete disruption of the cell death machinery can be lethal, but many mutations of the regulatory machinery yield only modest or no phenotypes, indicating substantial redundancy and compensation of regulatory mechanisms. Most of the deaths are apoptotic and are identified by techniques used to recognize apoptosis, but techniques identifying lysosomes (whether in dying or involuting cells or in the phagocytes that invade the tissue) also reveal patterns of cell death. Aberrant cell deaths that produce known phenotypes are typically localized, indicating that the mechanism of activating a programmed death in a specific region, rather than the mechanism of death, is aberrant. These results lead us to conclude that we need to know much more about the conversations among cells that lead cells to commit suicide.
\end{abstract}

KEY WORDS: apoptosis, autophagy, caspase, necrosis, programmed cell death

\section{Cell death in development - a historical perspective}

Cell death is a fundamental aspect of normal embryonic differentiation, morphogenesis, and teratogenesis, as well as of many diseases. Our understanding of these facts stems from considerable research as well as from old and very recent information. The great $19^{\text {th }}$ century embryologist, Carl Vogt, saw cell death in embryos as early as 1842 (Vogt, 1842), and by 1885 Walter Flemming documented the obvious, that loss of tadpole structures during metamorphosis resulted from cell death (Flemming, 1885). Throughout the early $20^{\text {th }}$ Century, many researchers examined the death of larval tissues in metamorphosing insects. By mid-century, Levi-Montalcini and Hamburger had demonstrated that the same number of neurons were born in each sympathetic or sensory ganglion, whether or not the ganglion supported a limb(Hamburger and Levi-Montalcini, 1949). Subsequently, in segments of the spinal cord that did not support a limb, many of the neurons died, resulting in much smaller ganglia(Hamburger and Levi-Montalcini, 1949). These investigations ultimately led to the discovery of nerve growth factor, and its role as a diffusible agent (Levi-Montalcini and Hamburger, 1953). Meanwhile, John Saunders and Edgar Zwilling, studying the mechanisms of differentiation of chick limbs, noted patches in the limbs, notably in the interdigital spaces, the axilla of the limbs, and (as previously noted by Dame Honor Fell) in the chondrogenic regions of the limbs, in which cells died (Fallon and Saunders, 1968, Saunders, 1966). These studies would later lead to experiments that demonstrated that the cell death in limbs could be determined before it was completely committed, as is described below. Glücksmann laboriously cataloged the numerous instances of cell death in embryos and throughout life, attempting to group them according to their biological purpose (Glucksmann, 1951, Glucksmann, 1965, Glücksmann, 1930). While this classification may seem artificial today, he clearly described cell death in em-

Abbreviations used in this paper: CHX, cycloheximide; CNS, central nervous system; ICM, inner cell mass; MIS, Mullerian inhibiting substance; MZT, maternal zygotic transition; PCD, programmed cell death; RA, retinoic acid. \footnotetext{
e-mail: zahra_zakeri@ hotmail.com

Accepted: 22 May 2015.

ISSN: Online 1696-3547, Print 0214-6282

*Address correspondence to: Zahra Zakeri. Queens College and Graduate Center, Department of Biology, City University of New York, NY, USA. 
bryonic organs as a normal biological process.

Meanwhile, in very different fields and late in the $20^{\text {th }}$ Century, others acknowledged the importance of cell death in embryonic development. Immunologists recognized that the variety and specificity of the immune system derived from a massive overproduction and death of thymocytes (Budd, 1998). Endocrinologists recognized the dual sexuality of early vertebrate embryos, with sexual differentiation stemming from the degeneration of the Müllerian system in males and the Wolffian ducts in females (Dyche, 1979). Insect physiologists defined programmed cell death(Lockshin and Williams, 1964, Lockshin and Williams, 1965a, Lockshin and Williams, 1965b, Lockshin and Williams, 1965c, Lockshin and Williams, 1965d). And, finally, the genetics of apoptosis were first defined for the embryonic development of the worm Caenorhabditis elegans (Ellis and Horvitz, 1986, Horvitz, 2003, Horvitz et al., 1994, Horvitz et al., 1983).

Thus the widespread appearance of cell death as a developmental process was readily acknowledged, but acceptance of the idea that it was a controlled process came relatively late. This was surprising: as one of us argued many years before, if a developmental cell death can be predicted, it is a genetic trait as much as color, shape, or number of spines is a genetic trait. The demonstration that death was controlled came from two sets of experiments. In chick embryos, Saunders and his associates explanted the cells that were destined to become part of the "posterior necrotic zone" (an axillary zone in which cells die) and observed that they would nevertheless die on schedule. These cells however were not moribund or irreversibly damaged, since, transplanted to the back of another chick, they could heal into the back of the chick and survive and differentiate (Fallon and Saunders, 1968, Saunders, 1966). Studying the fate of the intersegmental muscles of metamorphosing moths, Lockshin and Williams documented a sequence of clearly biological steps, subject to physiological regulation, that led to the death of larval muscles (Lockshin and Williams, 1964, Lockshin and Williams, 1965a, Lockshin and Williams, 1965b, Lockshin and Williams, 1965c, Lockshin and Williams, 1965d).

Finally, Horvitz, Sulston, Brenner, and colleagues demonstrated that the death of 131 cells of the 1,090 in an embryonic nematode was completely predictable (Horvitz et al., 1994) and that the deaths of these cells was controlled by a limited number of genes; their genetic pursuits ultimately led to the identification of the first major gene for apoptosis, which turned out to encode a highly conserved cysteinyl protease (Horvitz et al., 1994).

Today we recognize that cell death shapes and sculpts the developing embryo in both vertebrates and invertebrates: opening lumina, deciding boundaries, and preparing lines of fusion. Evolutionary selection for physical traits in adults, for instance loss of a tail in vertebrates or disappearance or fusion of limbs, is often established by the embryonic appearance of these organs, which serve as the substratum for further development, followed by their failure to continue to grow and ultimately by their elimination through timed and controlled cell death. Many embryonic malformations and teratologies result from interference with these patterns of cell death. In mature animals, many cancers and autoimmune diseases result from the failure of homeostatic cell death.

The process of cell death is an evolutionarily conserved phenomenon, both in the structure of the pathways of cell death and in the molecules that create these pathways(Punj and Chakrabarty, 2003). In embryos and developing organisms, cell death is exqui- sitely controlled, such that limbs (Zuzarte-Luis and Hurle, 2002), digits (Montero and Hurle, 2010), and phalanges (Montero and Hurle, 2010) are routinely perfect, with the smallest aberrations being readily recognizable, as, for instance, are malformations of the earlobes, the palates that make up the face (McGonnell et al., 1998), the internal and external sexual organs (Wilson and Davies, 2007) and the interiors of our organs (Murray and Edgar, 2000). Although as many as $2 / 3$ of the neurons that are born die before the brain completes its development, the wiring of our nervous system is remarkably consistent (Chu-Wang and Oppenheim, 1978). How this is accomplished is well worth understanding.

\section{Types and characterization of cell death}

Cell deaths were long classified into three types: apoptosis (Type I), Iysosomal/autophagy (type II), and necrosis, with an ever-growing list of variants such as necroptosis and autosis, which seem to be narrowing the gap among cell death types. Whereas the focus of this review is on cell death generally and development, it is useful to discuss distinguishing hallmarks among the classical types of cell death that are often seen in development. Of the three classical categories of cell death, apoptosis and type II lysosomal / autophagy are classified as programmed cell death (PCD, under biological control), and necrosis was previously described as unregulated, though new insights have led to recognition of a potential regulation of necrotic death (Sun and Wang, 2014). Each type of cell death is represented by unique features, with boundaries that are still being described, and with a considerable crosstalk and crossover among types. Below we describe characteristics that are most representative of each type, acknowledging that these distinctions are based on relative sensitivities to and duration of stimuli and thresholds of response, as opposed to being discretely expressed by each cell death type.

\section{Apoptosis (PCD type I)}

Apoptosis is characterized by a cell's loss of adherence to neighboring cells as well as to extracellular matrix (Taylor et al., $2008 \mathrm{~b})$. The term reflects a sequence of morphological changes that include cell rounding, rounding and fragmentation of nuclei, and condensation of nuclear chromatin (Taylor et al., 2008b). Condensation of chromatin is generally coincident with fragmentation of DNA (Tone et al., 2007). These morphological characteristics follow mitochondrial release of cytochrome $\mathrm{c}$, resulting in a cascaded activation of caspases, proteolytic enzymes, leading to the controlled death of the cell (Skulachev, 1998). The destruction by caspases of the cytoskeleton and nucleoproteins explains most of the morphological changes (Veselska et al., 2003). Ultimately, cells fragment into blebs, which are consumed by phagocytes attracted by phosphatidylserine exteriorized by the cells in the final stages of apoptosis (Taylor et al., 2008a). Apoptosis is initially considered potentially reversible, until activation of caspases, at which point the cell is destined to die (Owens et al., 2009). Because of the irreversibility of cell death, there exists a debate in distinguishing between early stages of apoptosis and those of autophagic cell death, discussed below.

\section{Lysosomalautophagic (PCD type II)}

Some of the earliest descriptions of the morphology of programmed cell death focused on extensive involvement of lysosomes. 
Many of these studies considered large cells with massive cytoplasm in metamorphosing insects (Beaulaton and Lockshin, 1982, Lockshin and Williams, 1965d) and tadpoles (Weber, 1969), and physiological regulation like postlactational involution of mammary epithelium (Helminen et al., 1968). Today we would consider the process to be macroautophagy or, more simply, autophagy. Autophagy is characterized by large autophagic (lysosomal) vacuoles that consume the bulk of the cytoplasm (Codogno, 2014). Unlike apoptosis, this type of programmed cell death is not characterized by rapid destruction of DNA; and the original cell is not easily phagocytosed, as its cytoplasm is bulky (Codogno, 2014). In the earlier hypotheses, autophagy was considered to be a mechanism by which cells committed suicide (Tsujimoto and Shimizu, 2005). However, autophagy is more frequently seen as a means by which a cell, under duress, eliminates damaged organelles or macromolecules or otherwise digests intracellular materials to generate more energy so that the cell can resist the strain (Das et al., 2012). It is commonly seen when cells are starved or, because of hormonal or other issues, are unable to import nutrients (Russell et al., 2014). In programmed cell death, autophagy seems to differ only in that it is not self-limiting (Moreau et al., 2010). When PC12 cells that had differentiated into neurons were deprived of nerve growth factor, their death became irreversible when the mitochondria had been consumed (Tolkovsky, 2009, Tolkovsky et al., 2002, Xue et al., 2001). In metamorphosing insect labial glands, DNA cleavage, characteristic of apoptosis, became detectable once $\sim 80 \%$ of the cell cytoplasm had been destroyed (Zakeri et al., 1993). Although it is unlikely that autophagy initiates the agony of the cell rather than responding to it, the term "autophagic cell death" retains the utility of describing a form of death characterized by massive autophagy and suggesting that the death is brought about by penury of energy or other resources (Loos et al., 2013).

Both apoptotic and autophagic cell death have been frequently identified during development, playing a critical role in removing unwanted cells, restricting cell numbers, and assisting tissue patterning during development (Chanoine and Hardy, 2003, Coucouvanis et al., 1995, Glucksmann, 1951), as will be discussed below. However, more recently several laboratories have documented the control of necrotic processes that may also function in development (as, for instance, in the death of osteoblasts and osteoclasts deep within bone, to which phagocytes have very limited access).

\section{Necrosis}

Necrosis is characterized by uncontrolled cell death, generally resulting from high stress, such as acute injury (Golstein and Kroemer). Rapid changes in critical ions, osmolarity, and pH lead to cell lysis (Golstein and Kroemer). Cell membranes become leaky and burst (Ono et al., 2003). Differing from apoptosis and autophagy, necrosis is characterized by exhaustion of energy resources or inability of generation of energy to keep up with demand, such as for the maintenance of ion pumps (Edinger and Thompson, 2004). This type of cell death is disruptive and generally elicits inflammatory responses.

Since necrotic cell death can occur during development and can manifest specific molecular patterns such as protection by necrostatin - in a programmed manner - additional classes of necrosis (necroptosis) have been defined and are considered to be programmed(Sun and Wang, 2014). Furthermore, because of crosstalk among the different cell death types, depending on the intensity, duration, and extent of the stimulus, cells can die manifesting a sequence of apparent types of death (Edinger and Thompson, 2004). For instance, as above, a cell may destroy its cytoplasm by autophagy and finally undergo apoptosis, or a cell may embark on an apoptotic pathway, but deplete its energy before completing the process, and ultimately become necrotic (Vanden Berghe et al., 2010). Apoptotic cells that are not phagocytosed ultimately undergo necrosis (Vanden Berghe et al., 2014, Vanden Berghe et al., 2010).

\section{Cell death in the germ line}

Apoptosis operates during gametogenesis as elsewhere to eliminate defective cells, in this case germ cells (oocytes and spermatocytes) suffering chromosomal or other damage(Arama et al., 2003, Arama et al., 2007, Baum et al., 2007, Bergmann et al., 1998, McCall and Steller, 1998) as well as to reduce the number of oocytes that will be nourished and permitted to grow. The substantial loss of most of the oocytes that were originally formed, late in embryogenesis and throughout adolescent and adult life in mammals is through controlled apoptosis. Since administration of excess gonadotrophins can produce superovulation, the primary hypothesis is that the oocytes that die initiate maturation but fail to acquire adequate gonadotrophin; the mechanism, however, remains mysterious (Teixeira et al., 2001). The remnants of those that matured to ovulation, the corpora lutea, ultimately undergo apoptosis, similar to the death of follicle cells and nurse cells in invertebrates (Teixeira et al., 2001). In Drosophila, cell death in mid-oogenesis resembles apoptosis morphologically and is caspase-dependent, although the upstream activators differ from those used in most apoptotic cell deaths in the fly (McCall, 2004, Pritchett et al., 2009). The first gene shown to be required for cell death in mid-oogenesis was the effector caspase gene Dcp-1 (Laundrie et al., 2003). Dcp-1 null flies produce "undead" egg chambers with uncondensed nurse cell nuclei and a loss of the surrounding follicle cells. Undead egg chambers are also observed with over-expression of DIAP1 or p35 (Baum et al., 2007, Mazzalupo and Cooley, 2006, Peterson et al., 2003). Cell death in the germline of a wild-type fly occurs primarily at three stages of egg chamber development: in the germarium before the follicle cell layer forms, in pre-vitellogenic stages, and as the egg nears maturation (Buszczak and Cooley, 2000, McCall, 2004, Pritchett et al., 2009). Whereas late stage death occurs during the development of every egg, cell death in the germarium and pre-vitellogenic stages occurs sporadically in well-fed flies (Barth et al., 2011, Drummond-Barbosa and Spradling, 2001, Nezis et al., 2009). These distinct forms of cell death in oogenesis involve multiple mechanisms, including apoptosis, autophagic cell death, and other pathways (Jenkins et al., 2013, Krysko et al., 2008).

A compelling story is that of sperm individualization. All spermatocytes begin life as syncytial cells with conventional amounts of cytoplasm. They ultimately separate and differentiate when a contracted ring of actin moves from the nucleus or head of the sperm toward the distal end of the tail, squeezing away the bulk of the cytoplasm into a "waste bag" and leaving only the sperm tail. The waste bag is destroyed in an apoptosis-like process. Caspases are active in the spermatocyte and are necessary for the maturation of the sperm (Arama et al., 2003, Baum et al., 2007). Furthermore, since this is an apoptosis-like process in that only part of the cell is destroyed while the rest survives to differentiate as a spermatozoan, the means by which the process is spatially 
and temporally controlled needs to be understood. There are many other instances in which partial apoptosis is seen, such as in the elimination of organelles from lens fibers and erythrocytes, the maturation of megakaryocytes into platelets (Zauli et al., 1997), and perhaps the differentiation of keratinocytes into corneocytes (Candi et al., 2005, Mammone et al., 2000).

In non-mammalian vertebrate embryos, apoptosis is typically not seen prior to gastrulation, with some authors arguing that apoptosis is not seen until the maternal-zygotic transition (Negron and Lockshin, 2004). The maternal-zygotic transition (MZT) is the period during which the embryo begins to make its own messenger RNA and cleavage becomes asynchronous, typically between the 8 and 12division (256 to 4096 cells) (Lee et al., 2014). The failure of pre-MZT embryos to manifest apoptosis is typically attributed to either blockage of apoptosis machinery or absence of some component of the machinery. In our hands, the failure appears to be an artifact of aquatic embryos, especially fresh-water embryos like zebrafish. Pre-MZT embryos exposed to toxins activate caspase 3 in a manner equivalent to post-MZT embryos, but the cells lyse almost immediately thereafter, whereas the cells of older embryos survive two more hours and thus can manifest the typical morphology and biochemistry of apoptosis (Fig. 1) (Negron and Lockshin, 2004). There is an assumption that there is something special about this transition, perhaps with inhibitors of apoptosis existing prior to the transition or the machinery of apoptosis having to be synthesized by the zygote (Greenwood and Gautier, 2005, Hensey and Gautier, 1997). The lack of cell death, however, appears to be an artifact of the experimental situation: Pre-MZT zebrafish embryos contain caspase- 3 and can activate it quite efficiently when the eggs are exposed to various toxins, but the cells of these

Fig. 1. Early vertebrate embryos are capable of undergoing apoptosis, but apoptosis is not seen. (Top row) Activated but unfertilized zebrafish eggs (U) undergo abortive development, begin to deteriorate at $3 \mathrm{~h}$ (U3) and are dead by $8 \mathrm{~h}$ (U8). (Second row) Fertilized eggs exposed to $100 \mu \mathrm{g} / \mathrm{ml}$ cycloheximide $(\mathrm{CHX})$ at $2 \mathrm{~h}$ post fertilization $(2+0)$ are dead $5 \mathrm{~h}$ later $(2+5)$. Cells begin to dissociate from the embryo beginning at $3 \mathrm{~h}$ (arrows). (Third row) Progress of a normally fertilized egg from within minutes of fertilization (FO) through the first $8 \mathrm{~h}$ (F8). F7F8 is the period known as "germ ring."(Fourth row) 64-cell stage (approximately 2 h, F2, left image of pairs) exposed to $\mathrm{CHX}$ fail to manifest signs of apoptosis 4 or $5 \mathrm{~h}$ later, while apoptosis is readilyapparent in similarly exposed 64 CHX embryos (64 GR, F7, right image of pairs). (Left pair) DAPI staining of nuclei, showing typical condensation and fragmentation in the older embryos; (Center pair) Electron micrographs, showing typically apoptotic nucleus in the older embryo; (Right pair) TUNEL staining, indicating lack of fragmentation of DNA in 64-cell embryos but substantial fragmentation in the disintegrated nuclei of the olderembryos. (Fifth row) Electrophoresis of DNA from $\mathrm{CHX}$-exposed 64-cell embryos (left) does not indicate clear laddering of low molecular weight DNA, while such laddering is readily apparent in DNA from germ

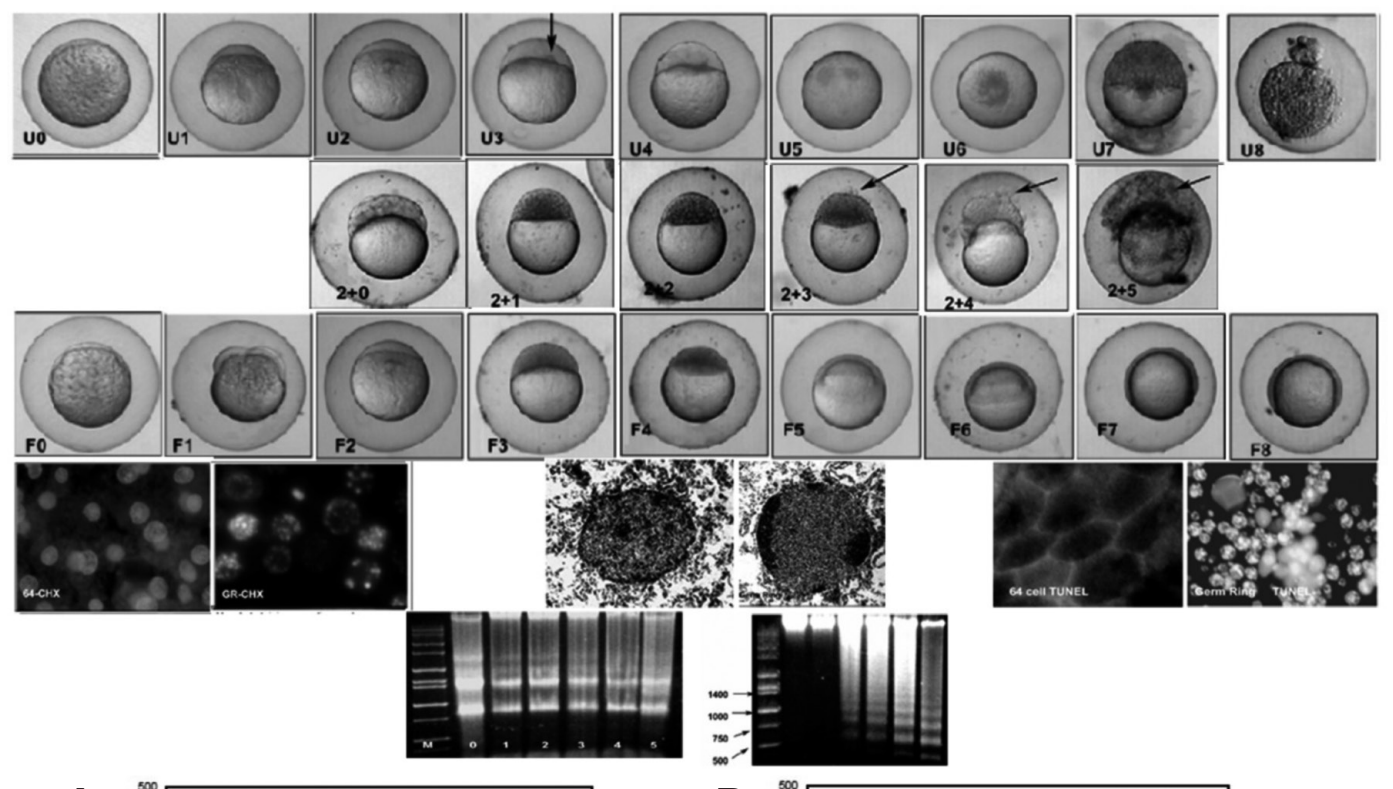

A

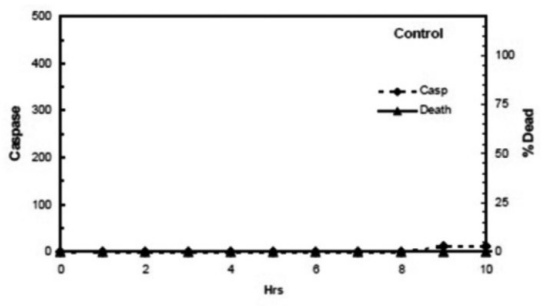

C

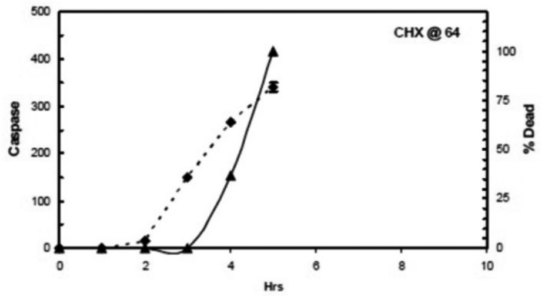

B

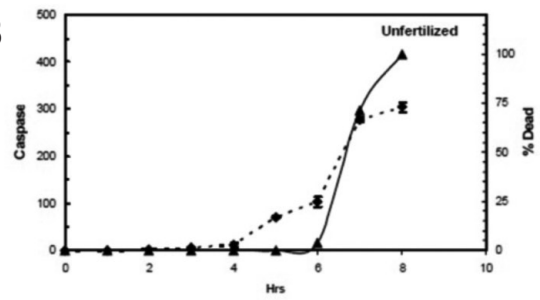

D

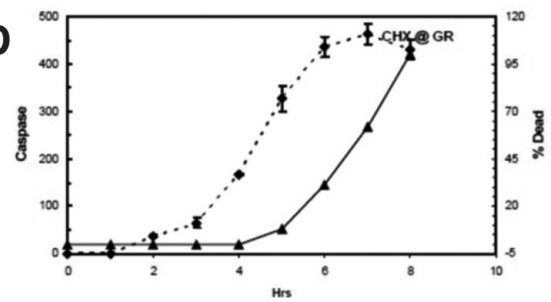

ring embryos (right). The four graphs indicate a possible explanation for these differences. There is essentially no activation of caspase-3 (dashed line, measured by cleavage of fluorogenic substrate) or death (solid line) in control fertilized eggs (A). Unfertilized eggs (B) activate caspase-3 between 5 and $6 \mathrm{~h}$; over $80 \%$ are dead by $7 \mathrm{~h}$; and all are dead by $8 \mathrm{~h}$. Fertilized eggs exposed to CHX at $2 \mathrm{~h}$ (C) begin to activate caspase-3 within $1 \mathrm{~h}$, are dying by $2 \mathrm{~h}$ after exposure, and are dead by $3 \mathrm{~h}$ after exposure. In contrast, germ-ring embryos exposed to CHX (D), activate caspase-3 on approximately the same schedule but do not begin to die until $5 \mathrm{~h}$ after exposure and are not all dead by $9 \mathrm{~h}$. This delay permits the cells to progress into morphological signs of apoptosis. From doctoral research of Javier Negron at St. John's University (2004). 
freshwater embryos lyse very shortly after caspase-3 is activated and do not have the time to develop the classic characteristics of apoptosis (Negron and Lockshin, 2004). Later, post-MZT, embryos do not lyse for at least two hours after activating caspase-3, and therefore have ample opportunity to manifest morphological and biochemical characteristics of apoptosis (Negron and Lockshin, 2004). The difference appears to reside in the fragility of the preMZT cells. Whether this fragility derives from the greater size of the cells and consequent decreased relative strength of the cell membranes or from some more profound biological or biochemical cause has not been determined (Negron and Lockshin, 2004).

Since mammalian embryos create a placenta and for this process have interpolated into their development the compaction and expansion of the blastocyst, they are quite different. Zygotic gene activity begins as early as the two-cell stage, and the earliest patterned or predictable death occurs as the compacted blastocyst begins to expand, when one or two cells die at the junction of the inner cell mass and the trophoblast(Byrne et al., 1999, Leidenfrost et al., 2011, Zakeri et al., 2005). Caspase activity is important to the embryo, as exposure of embryos to a broad-spectrum caspase inhibitor (zVAD-fmk) between the two-cell and four-cell stage leads to a failure of expansion, with cell death beginning at the ICM-trophoblast junction and finally engulfing the entire embryo (Zakeri et al., 2005). Although we assume that this is an issue of cell death, we have not yet ruled out activities of caspases that have nothing to do with cell death or nonspecific activities of the inhibitor. Leidenfrost et. al., document that in vitro as well as in vivo in cows, the first four cleavage cycles are prone to a high failure rate including different types of permanent cell cycle arrest and subsequent non-apoptotic blastomere death. In vitro produced and in vivo derived blastocysts showed a significant incidence of cell death in the inner cell mass (ICM), although morphological features of apoptosis were only partially present, and transcripts for CASP3, CASP9, CASP8 and FAS/FASLG were not detectable or found at very low abundance (Leidenfrost et al., 2011).

\section{Cell death during organogenesis}

In organogenesis, cell death is pivotal in orchestrating the formation of functional organs from a group of well-organized cells. Most studies of cell death in vertebrate embryos have been conducted using frog, chicken, or fish embryos. In all vertebrate embryos, organogenesis involves considerable amounts of cell death. Many of the deaths are scattered throughout the embryo and our inability to track cell lineage prevents us from evaluating the extent to which the death of specific cells is determined (as has been done, for instance, for Caenorhabditis (Horvitz et al., 1994)). However, in specific regions it is apparent that morphogenesis involves both the burgeoning of rapidly-growing tissues and death of others to generate separations or lacunae. Most separations of tissue layers, such as between the parietal and visceral parts of the somitic musculature; and most appearances of lacunae, such as the openings of the bronchi and alveoli, the differentiation of the cardiac chambers, and the glomeruli, to some extent involve cell deaths (Penaloza et al., 2006).

Cell death is integral to tissue remodeling as well as organogenesis. In Drosophila, the hormone ecdysone triggers cell death in the larval midgut (Lee et al., 2002). In tadpoles, tail regression and gill destruction result from controlled cell death dependent on rising concentrations of thyroxine(Jeffery, 2002). Separation of the lens from the cornea takes place as a result of cell death (as the lens forms, the nuclei of the lens fiber cells fragment their DNA and eventually disappear, giving rise to the clear lens fiber cells as a partial apoptosis) (Gao et al., 1997, Gupta et al., 2002). Other deaths are seen in the formation of olfactory pits(Pellier and Astic, 1994); in the formation of the cloaca in fish (Pyati et al., 2006); along the margins of the somites (Jeffs and Osmond, 1992, Sanders, 1997); and between the digits and in the axilla of developing limbs (Zuzarte-Luis and Hurle, 2002). Primarily because of ease of access, these tissues have received the most attention, but there are undoubtedly many other instances of cell death in the embryo. Thus, the distribution of deaths is specific even within tissues and organs (Fig. 2). Much of our knowledge of embryonic cell death
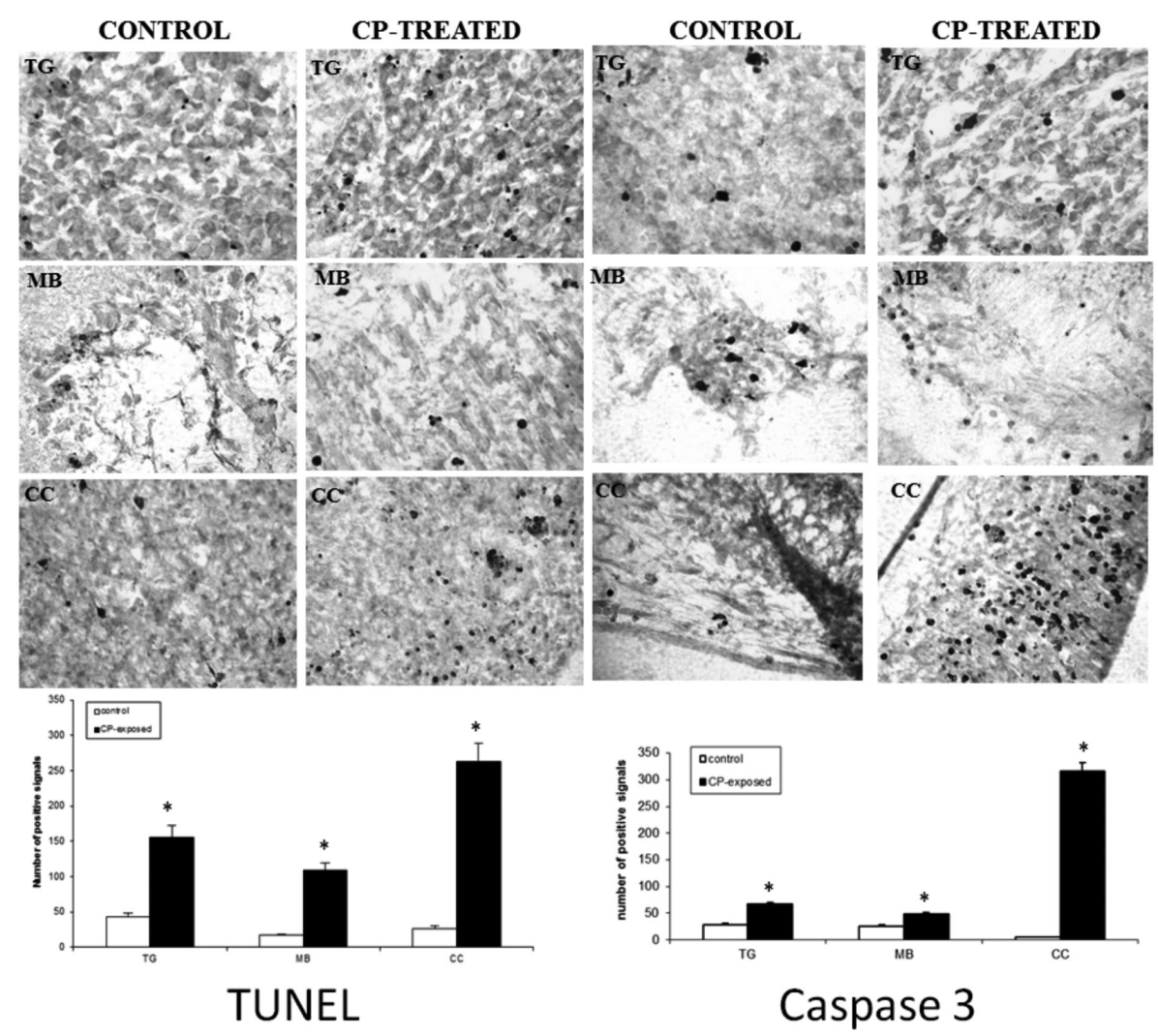

Fig. 2. Cell death in $\mathbf{1 2 . 5}$ day embryonic mouse brains. The amount of spontaneous cell death, measured by TUNEL (left) or antibody for activated caspase-3 (right) varies among regions of the brain, and the regions of the brain differ substantially in sensitivity to cyclophosphamide. TG: trigeminal ganglion; MB: midbrain; CC: region that will differentiate into cerebral cortex. While the manifestations change, the patterns of cell death are the same in mice lacking, through knockout, either caspase 3 or bim (data not shown). From doctoral research of Yixia Ye. 
has come from investigation of abnormal cell death due to genetic or chemical manipulation. Cell death in development has benefited from the field of teratology. Study of abnormal amounts of cell death has helped to define the mechanism of action of teratogens. In mammals $50 \%$ or more of the neurons produced during neurogenesis die before maturation of the central nervous system (CNS) (Lossi \& Gambino 2008). As presented in Figure 2, the amount of spontaneous cell death in later development differs in different parts of the CNS, and the different regions are also differentially sensitive to teratogens such as cyclophosphamide. Deaths may be apoptotic or may involve substantial activity of lysosomes, both within dying cells and in phagocytes (Fig. 3)

Earlier researchers had identified, as a major element of sex differentiation, the death of the Müllerian ducts in males and the Wolffian ducts in females (Dyche, 1979, Teixeira et al., 2001). The death of the Wolffian ducts appears to derive from the lack of embryonic androgens in female embryos(Dyche, 1979, Teixeira et al., 2001); but the Müllerian ducts are destroyed through an active response to the testis-derived Mullerian Inhibiting Substance (MIS). Some effort was expended to determine how MIS functioned, but full details are not forthcoming (Teixeira et al., 2001). In other situations in which cell death is commonly observed, the fusion of lateral plates along the midline of the forming face and most likely elsewhere, including perhaps the closing neural tube, appears to be secured by the death of cells along the midline, with a resulting greater adhesion generated by unknown means, and consequent fusion of the cells from the two sides (Cuervo and Covarrubias, 2004, Jiang et al., 2006, Vaziri Sani et al., 2005).

Apoptotic cell deaths shape the future inner ear structure in the day 5 chick embryo (Avallone et al., 2002); are essential in generating the overall four-chambered architecture of the heart (Abdelwahid et al., 2002); determine correct muscle patterning in moths (Fahrbach et al., 1994, Haas et al., 1995); and sculpt the limbs of all amniotes by removal of interdigital webs (Ballard and Holt, 1968, Hurle and Colombatti, 1996, Zakeri et al., 1994). Expression of apoptotic proteases, particularly caspase-3, as well as the Apoptosis Activating Factor apaf-1, have been deemed necessary for normal brain development (Yakovlev et al., 2001).

In brief, cell death, usually apoptotic, is a common and presumptively necessary component of morphogenesis. However, experimental access at the tissue or organ level is normally difficult, especially in mammalian embryos, and most of the reports of cell death have been descriptive. The consequences of deregulation of cell death have been explored by the use of mutations or, occasionally, gross interference with cell death machinery. Some of these experiments, which have proven instrumental to our understanding of cell death in development, are described below. We also outline the challenges that we still face.

\section{Consequences of deregulation of cell death}

We are now well aware of the occurrence of cell death in embryos, but the questions of interest remain: how important is it, what happens when cell death inappropriately fails or is too extensive, and how is cell death controlled?

In the simplest of situations, it is not obvious that cell death is very important. For instance, genetic prevention of all the embryonic cell deaths in $C$. elegans is not obviously a problem (Horvitz et al., 1994). The worms live and move about normally, though they may reproduce a bit more slowly. Preventing the death of the intersegmental muscles in moths likewise does not seriously interfere with their lives, though their lives as adults are quite short (approximately one week) (Lockshin and Williams, 1964, Lockshin and Williams, 1965a, Lockshin and Williams, 1965b, Lockshin and Williams, 1965c, Lockshin and Williams, 1965d). We have, however, little ability to judge the subtleties of the lives of worms or moths.

In vertebrate embryos, many morphological and developmental anomalies involve deregulation of the cell deaths that occur during organogenesis. Of course in most of these instances the role of cell death has not been evaluated as causal or secondary. For instance, there are far fewer deaths in the interdigital regions of the feet of ducks (where the webbing forms) than in feet of chickens (which are not webbed (Zuzarte-Luis and Hurle, 2002)). In mice, the Hammertoe mutation produces a similar lack of cell
Fig. 3. Spontaneous cell death in developing zebrafish embryos. (A,B,C) Caspase-3, revealed by hydrolysis of PhiPhilux $\otimes(\mathbf{A})$ At 25 h of development, the lens (L) separates from the cornea and retina (R). Arrows indicate caspase-positive cells. (B) At $33 \mathrm{~h}$, the olfactory placode opens. (C) At $28 \mathrm{~h}$, cell deaths are seen along the notochord as the spinal central nervous system begins to differentiate. (D,E,F) Lysosomal activity, detected by Lysotracker Red ${ }^{\circledR}$, is seen in dying cells and the phagocytes that consume them. (D) Lens at 36 h. Nuclei and organelles are disappearing from the lens fibers at this time. (E) $7 \mathrm{~h}$ later (43 h), lysosomalactivity has almost terminated, and will be absent by $45 \mathrm{~h}$. (F) The
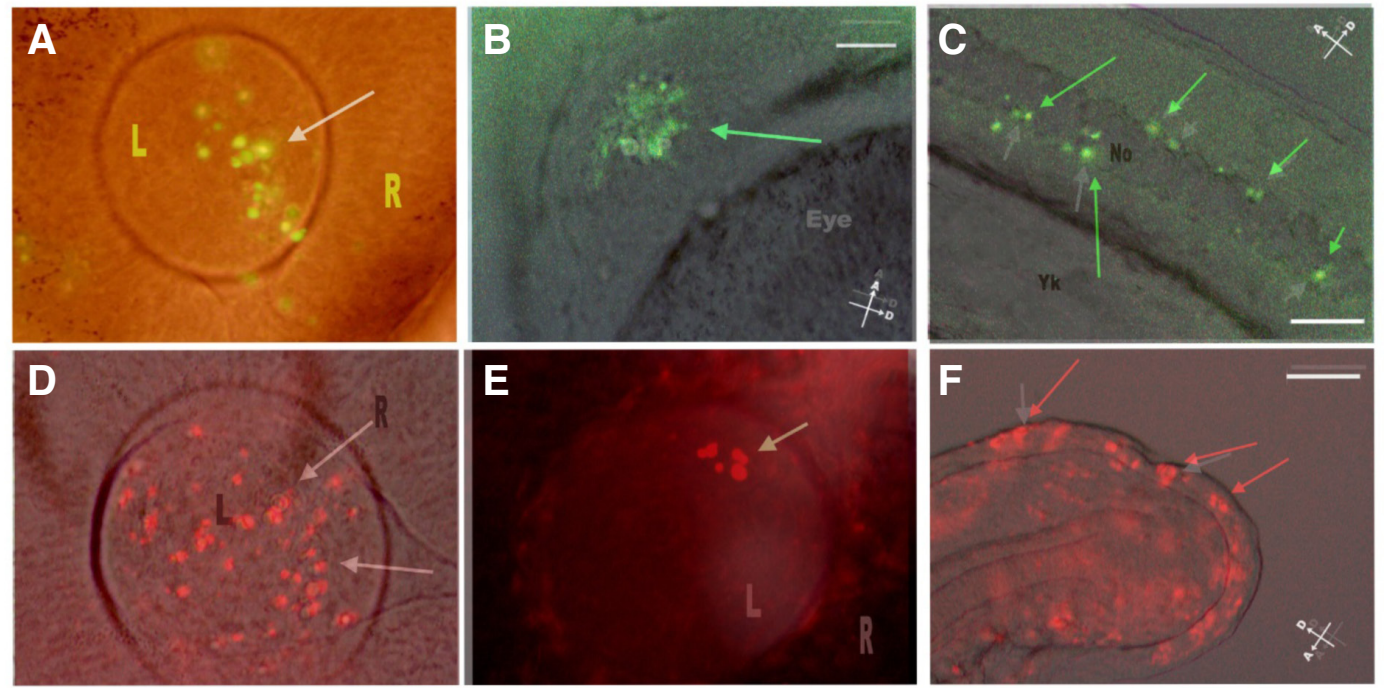

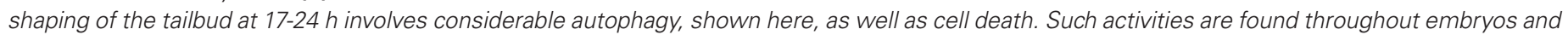
often open lumina, such as the cloaca (not shown). From doctoral studies of Nathaniel Abraham (2004, St. John's University). 

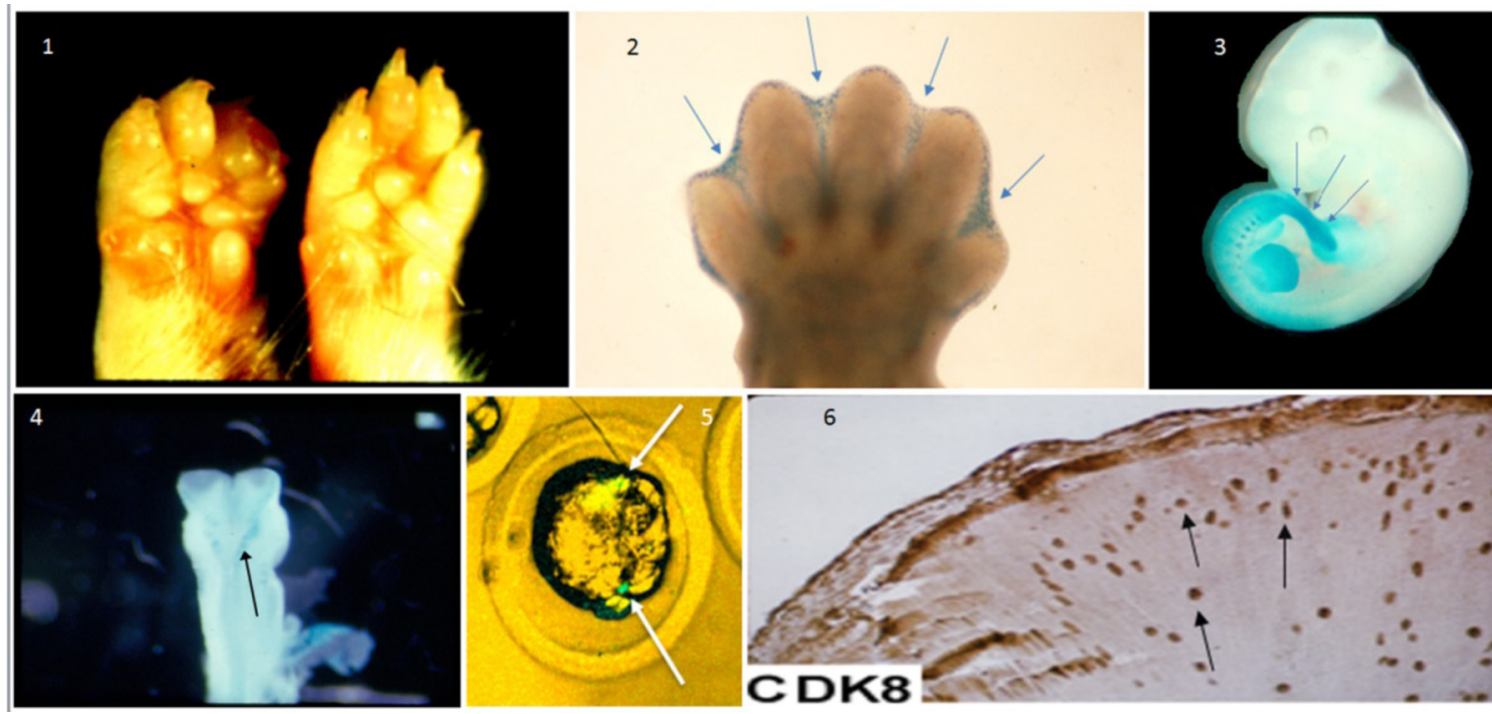

Fig. 4. Cell deaths in mammalian embryos. Dead or dying cells are indicated by arrows. (1) Hammertoe (left) and wildtype mouse limbs. Hammertoe is caused by failure of cell death in the interdigital spaces (see Zakeri and Ahuja, 1997). (2) Cell death in the interdigital spaces (Nile blue sulfate, taken up by phagocytes consuming dead cells) of the wildtype embryonic mouse forelimb palate. (3) Cell death in the mouse embryonic tail and along the spinal cord (Nile blue sulfate). (4) Nile blue sulfate reveals dying cells in the closing neural tube of a mouse embryo. (5) Acridine orange reveals dying cells at the junction of the inner cell mass and the trophoblast in a mouse blastocyst. (6) Dying cells upregulate CDK8 in differentiating lens.

death, resulting in webbing of the feet with disastrous results for the anatomical layout of the feet (Zakeri et al., 1994, Zakeri and Ahuja, 1997). Exposing mice in utero to excess retinoic acid (RA), which increases cell deaths throughout the embryo, increases the number of deaths within the interdigital region and partially or nearly completely rescues the defect in Hammertoe mutants (Zakeri et al., 1994, Zakeri and Ahuja, 1997). What is interesting here is that retinoic acid increases the number of deaths in the regions in which they would have been expected in wild-type mice, suggesting an innate, pattern-derived, difference in sensitivity of the cells in the interdigital regions (Zakeri et al., 1994, Zakeri and Ahuja, 1997). Likewise, cleft palate and hare lip appear to derive from a failure of cell deaths where the left and right maxillar prominences meet, but the reason for the failure of deaths has not been determined (Jiang et al., 2006). Clearly, these results suggest that the environment in which the cells find themselves -intimacy of contact with other cells? Access to circulation? Distance from cells generating pattern-forming substances? -renders some cells more susceptible to whatever signals trigger activation of their suicide mechanisms (Fig. 4) (Loos and Engelbrecht, 2009, Loos et al., 2013).

Likewise, failure of cell death in the immune system, owing to lack of Fas or Fas Ligand (apoptosis signal and receptor), appears at first to be inconsequential, but later in life the affected mice develop autoimmune disease and symptoms resembling lupus erythematosus (Wu et al., 1996). Such results are obtained for knockout of both Fas (the Ipr mouse) and for Fas Ligand (the gld mouse). At first appearance there are no profound morphological consequences, though ultimately the persistence of self-reactive thymocytes becomes a problem (Hahne et al., 1995). Similarly, knockout or knockin of presumptively even more generalized regulators of cell death, such as bcl- 2 or bcl-XL, frequently results in no immediately obvious phenotype. Most likely, redundancy of function and compensatory activities adjust the development of the embryo, so that disruption of the presumptively important gene has only minor consequences. Such an argument obtains, for instance, for knockout of Myo-D, the major gene committing cells to muscle differentiation (Chen et al., 2002). Overlapping and redundant functions of related genes compensate, so that the resulting embryo is only slightly abnormal.

When cell death is severely disrupted, as when the initiator caspase- 9 or the non-redundant regulator apaf- 1 are knocked out, the resulting phenotype is lethal, in which the embryos show failure of neural tube closure and apparently severe overgrowth of the brain (Kuida et al., 1998, Kuida et al., 1996, Leonard et al., 2002). Careful observation of apaf-1 mutant phenotypes reveals abnormal eye development, with notably thicker retina as well as a considerably smaller and incorrectly polarized lens when compared to wild-type littermates (Cecconi et al., 1998). Furthermore, these mutants develop brain hyperplasia (Cecconi et al., 1998). These characteristics make for very similar observations, with altered caspase-3 and BcIXL(Yakovlev et al., 2001). Activating molecule in Beclin 1-regulated autophagy (Ambra1) is crucial for nervous system development and is expressed from the first stages of neurulation with high specificity for the neural plate. Its loss of function leads to gross neural tube defects, such as exencephaly and spina bifida, which culminate in death in mice at around embryonic day16.5. Specific regulation of autophagosome formation via recruitment of Beclin 1 could conceivably take place in specific organs, responsible for tissue differentiation during embryogenesis (Fimia et al., 2007). However, it is not clear that this phenotype results from failure of cell death. There is considerable, perhaps normal, cell death in the brain, though the cells do not necessarily look apoptotic; and the spinal cord, in which similarly large amounts of cell death should occur, is of normal size. Thus the phenotype is not necessarily a direct result of the failure of cell death in the brain. In these instances the death process may be delayed, and the cells appear to use a nonapoptotic pathway of degeneration (Oppenheim et al., 2001). When examined, caspase-deficient neurons exhibit a nonapoptotic morphology in which nuclear changes such as chromatin condensation are absent or reduced; in addition, this morphology 
is characterized by extensive cytoplasmic vacuolization that is rarely observed in degenerating control neurons (Oppenheim et al., 2001, Yaginuma et al., 2001).

One limitation of studying cell death in mammalian embryos is that the physiological significance of cell death will be appreciated only in vivo, limiting most efforts to observations of normal and mutated embryos. Amore fundamental issue is that normal embryonic deaths are generally not decided by direct control of the cell death effector machinery. Rather, a combination of circumstances triggers cell death by creating a metabolic constellation that initiates (usually) the intrinsic or mitochondrial pathway to apoptosis. Efforts to override knock out, or knock in this pathway may result in aberrations in the intrinsic pathway. However, the circumstances that initiated the death are still operative, and most frequently, the death will still occur, though perhaps not by apoptosis, or the cell will survive but with minimal functionality. Thus the genetic manipulation will produce no measurable phenotype. The other consideration is that, for most genetic aberrations of cell death that produce viable phenotypes, the phenotype damage is specific to an organ or tissue, as is seen in Hammertoe, brachyury, cleft palate, and many similar mutations. In these cases, while the basis of the phenotype may be abnormal cell death, it is obvious that the problem lies in the invocation of the cell death process rather than in the machinery of cell death. This is quite different from what is seen in embryos that can be observed, such as those of the nematode Caenorhabditis and the fruit fly Drosophila. In these embryos, knockout of the primary cell death suppressing genes leads to massive and generalized cell death and early death of the embryo. In mutations such as Hammertoe, the problem is with cell deaths in a particular location and pattern, and the pattern can be restored experimentally. In this case the cell death machinery still has the ability to function. It is the regulation to turn on the machinery that is disrupted, or the signaling that is altered by the genetic mutation. Thus the issue is either the weakness of the pattern or an increased robustness of the cells within the region of expected death. As is the case with most of these questions, the question ultimately returns to the biological means by which the command to die is issued-deprivation of nutrients or oxygen, production of a specific component dependent on a growth factor, adherence to a specific matrix or substratum, lack of congruence between growth stimuli and metabolic capability to grow, or other unknown mechanisms - as opposed to the mechanics of cell death itself. Thus as always the question returns to the mechanisms by which cells communicate with each other.

Recent work on cell death has suggested a narrow differentiation between a dying cell and that of a cell attempting to survive. Most cells that are stressed can initially appear to undergo autophagy, and later, if the stress persists: apoptosis. If time-lapse studies are followed for most induced cell deaths, it is likely that markers and morphological characteristics of autophagy are observed, just prior to commitment to apoptosis. The next section explores growing evidence of threshold requirements for triggering cell death, as manifest by autophagy during normal and abnormal mammalian development.

\section{Autophagy during mammalian development}

Autophagy is an evolutionarily conserved system that functions to degrade and recycle nutrients. In various models, autophagy has been described as essential for development, as is the case with nematodes and pre-implantation mouse embryos (Melendez et al., 2003, Takamura et al., 2011, Tsukamoto et al., 2008a, Tsukamoto et al., 2008b). It is important when nutrients are restricted, as during critical mammalian developmental stages such as pre-implantation development of embryos (Feuer and Rinaudo, 2012). Autophagic activity is low in unfertilized oocytes and increases shortly after fertilization (Mizushima and Levine, 2010). It is transiently suppressed between the late one-cell and middle two-cell stages and is then activated again after the late two-cell stage (Mizushima and Levine, 2010). Rates of formation of autophagosomes continue to increase through the four- to eight-cell phase (Mizushima and Levine, 2010). Complete loss of autophagy in oocytes, as seen in Atg5-knockout mice under the zona pellucida glycoprotein (Zp3) oocyte-specific promoter, halted proper development of embryos before the blastocyst phase, suggesting the need for autophagy during normal mouse development. Atg5-deficient oocytes fertilized by Atg5-null sperm fail to develop beyond the four- and eight-cell stages, but could develop if fertilized by wild-type sperm(Stephenson et al., 2009). A lack of autophagy from the start of oogenesis does not seem to affect oocyte formation or fertilization. It is not known whether the main role of autophagy in pre-implantation development is to provide nutrients to the growing embryo or to clear maternal proteins (Tsukamoto et al., 2008a, Tsukamoto et al., 2008b). Other possible consequences of deficiency of autophagy are also possible. Secondary effects on the ubiquitin-proteasome system may have an impact on the coordination of the levels of critical proteins required for regulating cell division. It is possible that some of these secondary consequences of compromised autophagy may explain the requirement for autophagy during development of T-cells. Deletion of Atg5 or Atg7 in T-cells was accompanied by a decrease in thymocyte and peripheral T-cell numbers and also resulted in a decrease in T-cell survival (Stephenson et al., 2009).

T-cell self-renewability and quiescence of hematopoietic stem cells at the precursor stage depends on autophagy of the mitochondria and the endoplasmic reticulum. During development in the thymus, autophagy regulates peptide presentation in stromal cells and professional antigen-presenting cells, which mediate thymocyte selection (Bronietzki et al., 2015).

Around the time of gastrulation of the mouse embryo, endosomes are internalized into large vacuoles by microautophagy. At this developmental stage, the embryo has a cylindrical structure in which the epiblast and extraembryonic ectoderm are surrounded by the visceral endoderm. The visceral endoderm is highly active in endocytosis and has a well-developed apparatus for this purpose. These apical vacuoles express lysosomal marker proteins including lysosomal-associated membrane protein (lamp) 1 and 2 and cathepsin proteinases, and accumulate endocytic tracers such as immunoglobulins and dextrans, suggesting that they are functionally equivalent to lysosomes (Wada et al., 2014). These features point toward a role for autophagy during gastrulation.

Macroautophagy has been detected during embryogenesis, when maternally delivered Atg5 mRNA/protein provides sufficient function for development within a few days of fertilization. Zygotic deletion of Atg5 leads to defective embryonic growth, where cell division is initiated but blastocysts are unable to form; these results imply that autophagy is required for this process, possibly to provide nutrition (Tsukamoto et al., 2008a, Tsukamoto et al., 2008b). Beclin is also required for progression of development. Beclin-deficient 
embryos develop into egg cylinders but are arrested at gastrulation (Yue et al., 2003). In addition, deletion of activating molecule in beclin-regulated autophagy (ambra) 1, a beclin-interacting protein, produces severe defects in neural tube closure in mice, as well as multiple defects in organogenesis in zebrafish (Benato et al., 2013, Fimia et al., 2007, Gioacchini et al., 2013).

At birth, sudden termination of the fetal nutrient supply from the mother presents a stressful situation for the newborn infant before it establishes breastfeeding. During this transition period, autophagy provides necessary nutrients to the infant through increased turnover of proteins. This requirement has been shown experimentally in a transgenic mouse model expressing GFPtagged LC3 to visualize autophagosomes in vivo (Ravikumar and Rubinsztein, 2004). In these mice, autophagy in various tissues increases soon after birth, peaks at $\sim 6 \mathrm{~h}$ after birth, and declines to basal levels within 24-48 h (Ravikumar and Rubinsztein, 2004, Ravikumar et al., 2008). Autophagy-deficient mice starve to death within the first day (Komatsu et al., 2005).

The idea that autophagy is important for neuronal development is also supported by observations that inactivation of Ulk1 (Atg1) in immature granule cells impairs axon outgrowth and differentiation of neurons. Ulk1 activity at the growth cone is thus crucial for the formation of fibers, and allows the progression of cerebellar development (Di Bartolomeo et al., 2010).

\section{Conclusions and summary}

Cell death is an important component in the shaping and sculpting of embryos, and we now know that cell death and cell death-like processes are likewise major aspects of gametogenesis. In most embryos there is little or no cell death prior to the maternal-zygotic transition, but in mammalian embryos characteristic deaths of one or two cells occur at the end of compaction and are apparently necessary for the separation of the trophoblast from the inner cell mass. Considerable sculpting of the embryo occurs by cell deaths during organogenesis, and appropriate cell numbers, especially in the CNS and in the immune system, are generated by massive overproduction of cells and selection of a few, with death of the rest. Complete disruption of the cell death machinery is lethal, but many mutations of the regulatory machinery yield only modest or no phenotypes, indicating substantial redundancy and compensation of regulatory mechanisms. Most of the deaths are apoptotic and are identified by techniques used to recognize apoptosis. Aberrant cell deaths that produce known phenotypes are typically localized, indicating that the mechanism of activating a programmed death in a specific region, rather than the mechanism of death, is aberrant. These results lead us to conclude that we need to know much more about the conversations among cells that lead cells to commit suicide.

\section{Acknowledgements}

This work was supported in part by funding from the NIHNIGMS (MARCUSTAR) grant T 34 GM070387 To ZZ. We thank Dr. Javier Negron and Nathaniel Abraham for the use of unpublished figures from their doctoral dissertations in the laboratory of RAL.

\section{References}

ABDELWAHID, E., PELLINIEMI, L.J. and JOKINEN, E. (2002). Cell death and differentiation in the development of the endocardial cushion of the embryonic heart.
Microsc Res Tech 58: 395-403.

ARAMA, E., AGAPITE, J. and STELLER, H. (2003). Caspase activity and a specific cytochrome $\mathrm{C}$ are required for sperm differentiation in Drosophila. Dev Cell 4: 687-697.

ARAMA, E., BADER, M., RIECKHOF, G.E. and STELLER, H. (2007). Aubiquitin ligase complex regulates caspase activation during sperm differentiation in Drosophila. PLOS Biol 5: e251.

AVALLONE, B., BALSAMO, G., TRAPANI, S. and MARMO, F. (2002). Apoptosis during chick inner ear development:someobservationsbyTEM andTUNELtechniques. Eur J Histochem 46: 53-59.

BALLARD, K.J. and HOLT, S.J. (1968). Cytological and cytochemical studies on cell death and digestion in the foetal rat foot: the role of macrophages and hydrolytic enzymes. J Cell Sci 3: 245-262.

BARTH, J.M., SZABAD, J., HAFEN, E. and KOHLER, K. (2011). Autophagy in Drosophila ovaries is induced by starvation and is required for oogenesis. Cell Death Differ 18: 915-924.

BAUM, J.S., ARAMA, E., STELLER, H. and MCCALL, K. (2007). The Drosophila caspases Strica and Dronc function redundantly in programmed cell death during oogenesis. Cell Death Differ 14: 1508-1517.

BEAULATON, J. and LOCKSHIN, R.A. (1982). The relation of programmed cell death to development and reproduction: comparative studies and an attempt at classification. Int Rev Cytol 79: 215-235.

BENATO, F., SKOBO, T., GIOACCHINI, G., MORO, I., CICCOSANTI, F., PIACENTINI, M., FIMIA, G.M., CARNEVALI, O. and DALLA VALLE, L. (2013). Ambra1 knockdown in zebrafish leads to incomplete development due to severe defects in organogenesis. Autophagy 9: 476-495.

BERGMANN, A., AGAPITE, J. and STELLER, H. (1998). Mechanisms and control of programmed cell death in invertebrates. Oncogene 17: 3215-3223.

BRONIETZKI, A.W., SCHUSTER, M. and SCHMITZ, I. (2015). Autophagy in T-cell development, activation and differentiation. Immunol Cell Biol 93: 25-34.

BUDD, R. (1998). Autoimmunity -a Disorder of Apotosis?. In: Lockshin RA, Zakeri Z, Tilly JL (eds.) When Cells Die: Research into Apoptosis and Programmed Cell Death. Wiley-Liss, New York279-288.

BUSZCZAK, M. and COOLEY, L. (2000). Eggs to die for: cell death during Drosophila oogenesis. Cell Death Differ 7: 1071-1074.

BYRNE, A.T., SOUTHGATE, J., BRISON, D.R. and LEESE, H.J. (1999). Analysis of apoptosis in the preimplantation bovine embryo using TUNEL. $J$ Reprod Fertil 117: 97-105

CANDI, E., SCHMIDT, R. and MELINO, G. (2005). The cornified envelope: a model of cell death in the skin. Nat Rev Mol Cell Biol 6: 328-340.

CECCONI, F., ALVAREZ-BOLADO, G., MEYER, B.I., ROTH, K.A. and GRUSS, P. (1998). Apaf1 (CED-4 Homolog) Regulates Programmed Cell Death in Mammalian Development. Cell 94: 727-737.

CHANOINE, C. and HARDY, S. (2003). Xenopus muscle development: from primary to secondary myogenesis. Dev Dyn 226: 12-23.

CHEN, J.C., RAMACHANDRAN, R. and GOLDHAMER, D.J. (2002). Essential and redundant functions of the MyoD distal regulatory region revealed by targeted mutagenesis. Dev Biol 245: 213-223.

CHU-WANG, I.W. and OPPENHEIM, R.W. (1978). Cell death of motoneurons in the chick embryo spinal cord. I. A light and electron microscopic study of naturally occurring and induced cell loss during development. J Comp Neurol 177: 33-57.

CODOGNO, P. (2014). Shining light on autophagy. Nat Rev Mol Cell Biol 15: 153-153.

COUCOUVANIS, E.C., MARTIN, G.R. and NADEAU, J.H. (1995). Genetic approaches for studying programmed cell death during development of the laboratory mouse. Methods Cell Biol 46: 387-440.

CUERVO, R. and COVARRUBIAS, L. (2004). Death is the major fate of medial edge epithelial cells and the cause of basal lamina degradation during palatogenesis. Development 131: 15-24.

DAS, G.,SHRAVAGE, B.V.and BAEHRECKE, E.H. (2012). Regulation and Function of Autophagy during Cell Survival and Cell Death. Cold Spring Harb Perspect Biol 4: a008813.

DI BARTOLOMEO, S., NAZIO, F. and CECCONI, F. (2010). The role of autophagy during development in higher eukaryotes. Traffic 11: 1280-1289.

DRUMMOND-BARBOSA, D. and SPRADLING, A.C. (2001). Stem cells and their progeny respond to nutritional changes during Drosophila oogenesis. Dev Biol 
231: $265-278$.

DYCHE, W.J. (1979). A comparative study of the differentiation and involution of the Mullerian duct and Wolffian duct in the male and female fetal mouse. $J$ Morphol 162: 175-209.

EDINGER, A.L. and THOMPSON, C.B. (2004). Death by design: apoptosis, necrosis and autophagy. Curr Opin Cell Biol 16: 663-669.

ELLIS, H.M. and HORVITZ, H.R. (1986). Genetic control of programmed cell death in the nematode C. elegans. Cell 44: 817-829.

FAHRBACH, S.E., CHOI, M.K. and TRUMAN, J.W. (1994). Inhibitory effects of actinomycin $D$ and cycloheximide on neuronal death in adult Manduca sexta. $J$ Neurobiol 25: 59-69.

FALLON, J.F. and SAUNDERS, J.W., JR. (1968). In vitro analysis of the control of cell death in a zone of prospective necrosis from the chick wing bud. Dev Biol 18: 553-570.

FEUER, S. and RINAUDO, P. (2012). Preimplantation Stress and Development. Birth Def. Res Part C, Embryo Today: reviews 96: 10.1002jbdrc.21022.

FIMIA, G.M., STOYKOVA, A., ROMAGNOLI, A., GIUNTA, L., DI BARTOLOMEO, S., NARDACCI, R., CORAZZARI, M., FUOCO, C., UCAR, A., SCHWARTZ, P. et al., (2007). Ambra1 regulates autophagy and development of the nervous system. Nature 447: 1121-1125.

FLEMMING, W. (1885). Über die bildung von richtungsfiguren in saugethiereiern beim untergang graaf'scher follikel. Arch Anat Physiol Jahrgang 1885: 221-244.

GAO, C.Y., ZAKERI, Z., ZHU, Y., HE, H. and ZELENKA, P.S. (1997). Expression of Cdk5, p35, and Cdk5associated kinase activity in the developing rat lens. Dev Genet 20: 267-275.

GIOACCHINI, G., DALLA VALLE, L., BENATO, F., FIMIA, G.M., NARDACCI, R., CICCOSANTI, F., PIACENTINI, M., BORINI, A. and CARNEVALI, O. (2013). Interplay between autophagy and apoptosis in the development of Danio rerio follicles and the effects of a probiotic. Reprod Fertil Dev 25: 1115-1125.

GLUCKSMANN, A. (1951). Cell deaths in normal vertebrate ontogeny. Biol Rev Camb Philos Soc 26: 59-86.

GLUCKSMANN, A. (1965). Cell death in normal development. Arch Biol (Liege) 76: 419-437.

GLÜCKSMANN,A. (1930). Über die Bedeutung von Zellvorgangen für die Formbildung epithelialer Organe. Zeitschrift fürAnatomie und Entwicklungsgeschichte 93:35-92.

GOLSTEIN, P. and KROEMER, G. Cell death by necrosis: towards a molecular definition. Trends Biochem. Sci. 32: 37-43.

GREENWOOD, J. and GAUTIER, J. (2005). From oogenesis through gastrulation: developmental regulation of apoptosis. Semin Cell Dev Biol 16: 215-224.

GUPTA, A., TSAI, L.H. and WYNSHAW-BORIS, A. (2002). Life is a journey: a genetic look at neocortical development. Nat Rev Genet 3: 342-355.

HAAS, A.L., BABOSHINA, O., WILLIAMS, B. and SCHWARTZ, L.M. (1995). Coordinated induction of the ubiquitin conjugation pathway accompanies the developmentally programmed death of insect skeletal muscle. J Biol Chem 270: 9407-9412.

HAHNE, M., PEITSCH, M.C., IRMLER, M., SCHRÓTER, M., LOWIN, B., ROUSSEAU, M., BRON, C., RENNO, T., FRENCH, L. and TSCHOPP, J. (1995). Characterization of the non-functional Fas ligand of gld mice. Int. Immunol. 7: 1381-1386.

HAMBURGER, V. and LEVI-MONTALCINI, R. (1949). Proliferation, differentiation and degeneration in the spinal ganglia of the chick embryo under normal and experimental conditions. J Exp Zool 111: 457-501.

HELMINEN, H.J., ERICSSON, J.L.E. and ORRENIUS, S. (1968). Studies on mammary gland involution: IV. Histochemical and biochemical observations on alterations in lysosomes and lysosomal enzymes. J. Ultrastruc. Res. 25: 240-252.

HENSEY, C. and GAUTIER, J. (1997). A developmental timer that regulates apoptosis at the onset of gastrulation. Mech Dev 69: 183-195.

HORVITZ, H.R. (2003). Nobel lecture. Worms, life and death. Biosci Rep23: 239-303.

HORVITZ, H.R., SHAHAM, S. and HENGARTNER, M.O. (1994). The genetics of programmed cell death in the nematode Caenorhabditis elegans. Cold Spring Harb Symp Quant Biol 59: 377-385.

HORVITZ, H.R., STERNBERG, P.W., GREENWALD, I.S., FIXSEN, W. and ELLIS, H.M. (1983). Mutations That Affect Neural Cell Lineages and Cell Fates during the Development of the Nematode Caenorhabditis elegans. Cold Spring Harb Symp Quant Biol 48: 453-463.

HURLE, J.M. and COLOMBATTI, A. (1996). Extracellular matrix modifications in the interdigital spaces of the chick embryo leg bud during the formation of ectopic digits. Anat Embryol (Berl) 193: 355-364.

JEFFERY, W.R. (2002). Programmed cell death in the ascidian embryo: modulation by FoxA5 and Manx and roles in the evolution of larval development. Mech Dev 118: 111-124.

JEFFS, P. and OSMOND, M. (1992). A segmented pattern of cell death during development of the chick embryo. Anat Embryol (Berl) 185: 589-598.

JENKINS, V.K., TIMMONS, A.K. and MCCALL, K. (2013). Diversity of cell death pathways: insight from the fly ovary. Trends Cell. Biol. 23: 567-574. (10.1016jj. tcb.2013.07.005).

JIANG, R., BUSH, J.O. and LIDRAL, A.C. (2006). Development of the Upper Lip: Morphogenetic and Molecular Mechanisms. Dev Dyn 235: 1152-1166.

KOMATSU, M., WAGURI, S., UENO, T., IWATA, J., MURATA, S., TANIDA, I., EZAKI, J., MIZUSHIMA, N., OHSUMI, Y., UCHIYAMA, Y. et al., (2005). Impairment of starvation-induced and constitutive autophagy in Atg7-deficient mice. J. Cell Biol. 169: 425-434

KRYSKO, D.V., DIEZ-FRAILE, A., CRIEL, G., SVISTUNOV, A.A., VANDENABEELE, P. and D'HERDE, K. (2008). Life and death of female gametes during oogenesis and folliculogenesis. Apoptosis 13: 1065-1087.

KUIDA, K., HAYDAR, T.F., KUAN, C.Y., GU, Y., TAYA, C., KARASUYAMA, H., SU, M.S., RAKIC, P. and FLAVELL, R.A. (1998). Reduced apoptosis and cytochrome C-mediated caspase activation in mice lacking caspase 9. Cell 94: 325-337.

KUIDA, K., ZHENG, T.S., NA, S., KUAN, C., YANG, D., KARASUYAMA, H., RAKIC, P. and FLAVELL, R.A. (1996). Decreased apoptosis in the brain and premature lethality in CPP32-deficient mice. Nature 384: 368-372.

LAUNDRIE, B., PETERSON, J.S., BAUM, J.S., CHANG, J.C., FILEPPO, D., THOMPSON, S.R. and MCCALL, K. (2003). Germline cell death is inhibited by P-element insertions disrupting the dcp-1jpita nested gene pair in Drosophila. Genetics 165: 1881-1888.

LEE, C.Y., COOKSEY, B.A. and BAEHRECKE, E.H. (2002). Steroid regulation of midgut cell death during Drosophila development. Dev Biol 250: 101-111.

LEE, M.T., BONNEAU, A.R. and GIRALDEZ, A.J. (2014). Zygotic genome activation during the maternal-tozygotic transition. Annu Rev Cell Dev Biol 30: 581-613.

LEIDENFROST, S., BOELHAUVE, M., REICHENBACH, M., GÜNGÓR, T., REICHENBACH, H.-D., SINOWATZ, F., WOLF, E. and HABERMANN, F.A. (2011). Cell Arrest and Cell Death in Mammalian Preimplantation Development: Lessons from the Bovine Model. PLoS ONE 6: e22121.

LEONARD, J.R., KLOCKE, B.J., D'SA, C., FLAVELL, R.A. and ROTH, K.A. (2002). Strain-dependent neurodevelopmental abnormalities in caspase-3-deficient mice. $J$ Neuropathol Exp Neurol 61: 673-677.

LEVI-MONTALCINI, R. and HAMBURGER, V. (1953). A diffusible agent of mouse sarcoma, producing hyperplasia of sympathetic ganglia and hyperneurotization of viscera in the chick embryo. J. Exp. Zool. 123: 233-287.

LOCKSHIN, R.A. and WILLIAMS, C.M. (1964). Programmed cell death-II. Endocrine potentiation of the breakdown of the intersegmental muscles of silkmoths. J Insect Physiol 10: 643-649.

LOCKSHIN, R.A. and WILLIAMS, C.M. (1965a). Programmed cell death-I. Cytology of degeneration in the intersegmental muscles of the pernyi silkmoth. $J$ Insect Physiol 11: 123-133.

LOCKSHIN, R.A. and WILLIAMS, C.M. (1965b). Programmed cell death-III. Neural control of the breakdown of the intersegmental muscles of silkmoths. $J$ Insect Physiol 11: 601-610.

LOCKSHIN, R.A. and WILLIAMS, C.M. (1965c). Programmed cell death-IV. The influence of drugs on the breakdown of the intersegmental muscles of silkmoths. J Insect Physiol 11: 803-809.

LOCKSHIN, R.A. and WILLIAMS, C.M. (1965d). Programmed cell death. V. Cytolytic enzymes in relation to the breakdown of the intersegmental muscles of silkmoths. $J$ Insect Physiol 11: 831-844.

LOOS, B. and ENGELBRECHT, A.M. (2009). Cell death: a dynamic response concept Autophagy 5: 590-603.

LOOS, B., ENGELBRECHT, A.M., LOCKSHIN, R.A., KLIONSKY, D.J. and ZAKERI, Z. (2013). The variability of autophagy and cell death susceptibility: Unanswered questions. Autophagy 9: 1270-1285.

MAMMONE, T., GAN, D., COLLINS, D., LOCKSHIN, R.A., MARENUS, K. and MAES D. (2000). Successful separation of apoptosis and necrosis pathways in $\mathrm{HaCaT}$ 
keratinocyte cells induced by UVB irradiation. Cell Biol. Toxicol. 16: 293-302.

MAZZALUPO, S. and COOLEY, L. (2006). Illuminating the role of caspases during Drosophila oogenesis. Cell Death Differ 13: 1950-1959.

MCCALL, K. (2004). Eggs over easy: cell death in the Drosophila ovary. Dev Biol 274: 3-14.

MCCALL, K. and STELLER, H. (1998). Requirement for DCP-1 caspase during Drosophila oogenesis. Science 279: 230-234.

MCGONNELL, I.M., CLARKE, J.D. and TICKLE, C. (1998). Fate map of the developing chick face: analysis of expansion of facial primordia and establishment of the primary palate. Dev Dyn 212: 102-118.

MELENDEZ, A., TALLOCZY, Z., SEAMAN, M., ESKELINEN, E.L., HALL, D.H. and LEVINE, B. (2003). Autophagy genes are essential for dauer development and life-span extension in C. elegans. Science 301: 1387-1391.

MIZUSHIMA, N. and LEVINE, B. (2010). Autophagy in mammalian development and differentiation. Nature Cell Biol. 12: 823-830.

MONTERO, J.A. and HURLE, J.M. (2010). Sculpturing digit shape by cell death. Apoptosis 15: 365-375.

MOREAU, K., LUO, S. and RUBINSZTEIN, D.C. (2010). Cytoprotective roles for autophagy. Curr. Opin. Cell Biol. 22: 206-211.

MURRAY, P. and EDGAR, D. (2000). Regulation of Programmed Cell Death by Basement Membranes in Embryonic Development. J. Cell Biol. 150: 1215-1221.

NEGRON, J.F. and LOCKSHIN, R.A. (2004). Activation of apoptosis and caspase-3 in zebrafish early gastrulae. Dev Dyn 231: 161-170.

NEZIS, I.P., LAMARK, T., VELENTZAS, A.D., RUSTEN, T.E., BJORKOY, G., JOHANSEN, T., PAPASSIDERI, I.S., STRAVOPODIS, D.J., MARGARITIS, L.H., STENMARK, H. et al., (2009). Cell death during Drosophila melanogaster early oogenesis is mediated through autophagy. Autophagy 5: 298-302.

ONO, K., KIM, S.O. and HAN, J. (2003). Susceptibility of Lysosomes to Rupture Is a Determinant for Plasma Membrane Disruption in Tumor Necrosis Factor AlphaInduced Cell Death. Molec. Cell Biol. 23: 665-676.

OPPENHEIM, R.W., FLAVELL, R.A., VINSANT, S., PREVETTE, D., KUAN, C.-Y. and RAKIC, P. (2001). Programmed Cell Death of Developing Mammalian Neurons after Genetic Deletion of Caspases. J. Neuroscience 21: 4752-4760.

OWENS, T.W., VALENTIJN, A.J., UPTON, J.P., KEEBLE, J., ZHANG, L., LINDSAY, J., ZOUQ, N.K. and GILMORE, A.P. (2009). Apoptosis commitment and activation of mitochondrial Bax during anoikis is regulated by p38MAPK. Cell Death Differ 16: 1551-1562.

PELLIER, V. and ASTIC, L. (1994). Detection of apoptosis by electron microscopy and in situ labelling in the rat olfactory pit. Neuroreport 5: 1429-1432.

PENALOZA, C., LIN, L., LOCKSHIN, R.A. and ZAKERI, Z. (2006). Cell death in development: shaping the embryo. Histochem Cell Biol 126: 149-158.

PETERSON, J.S., BARKETT, M. and MCCALL, K. (2003). Stage-specific regulation of caspase activity in Drosophila oogenesis. Dev Biol 260: 113-123.

PRITCHETT, T.L., TANNER, E.A. and MCCALL, K. (2009). Cracking open cell death in the Drosophila ovary. Apoptosis 14: 969-979.

PUNJ, V. and CHAKRABARTY, A.M. (2003). Redox proteins in mammalian cell death: an evolutionarily conserved function in mitochondria and prokaryotes. Cellular Microbiol. 5: 225-231.

PYATI, U.J., COOPER, M.S., DAVIDSON, A.J., NECHIPORUK, A. and KIMELMAN, D. (2006). Sustained Bmp signaling is essential for cloaca development in zebrafish. Development 133: 2275-84.

RAVIKUMAR, B. and RUBINSZTEIN, D.C. (2004). Can autophagy protect against neurodegeneration caused by aggregate-prone proteins? Neuroreport 15:2443-5.

RAVIKUMAR, B., SARKAR, S. and RUBINSZTEIN, D.C. (2008). Clearance of mutant aggregate-prone proteins by autophagy. Methods Mol Biol 445: 195-211.

RUSSELL, R.C., YUAN, H.-X. and GUAN, K.-L. (2014). Autophagy regulation by nutrient signaling. Cell Res 24: 42-57.

SANDERS, E.J. (1997). Cell Death in the Avian Sclerotome. Dev Biol 192: 551-563.

SAUNDERS, J.W., JR. (1966). Death in embryonic systems. Science 154: 604-612.

SKULACHEV, V.P. (1998). Cytochrome $c$ in the apoptotic and antioxidant cascades. FEBS Lett 423: 275-280.

STEPHENSON, L.M., MILLER, B.C., NG, A., EISENBERG, J., ZHAO, Z., CADWELL, K., GRAHAM, D.B., MIZUSHIMA, N.N., XAVIER, R., VIRGIN, H.W. et al., (2009).
Identification of Atg5-dependent transcriptional changes and increases in mitochondrial mass in Atg5-deficient T lymphocytes. Autophagy 5: 625-635.

SUN, L. and WANG, X. (2014). A new kind of cell suicide: mechanisms and functions of programmed necrosis. Trends Biochem. Sci. 39: 587-593.

TAKAMURA, A., KOMATSU, M., HARA, T., SAKAMOTO, A., KISHI, C., WAGURI, S. EISHI, Y., HINO, O., TANAKA, K. and MIZUSHIMA, N. (2011). Autophagy-deficient mice develop multiple liver tumors. Genes Dev 25: 795-800.

TAYLOR, R.C., CULLEN, S.P. and MARTIN, S.J. (2008a). Apoptosis: controlled demolition at the cellular level. Nat Rev Mol Cell Biol 9: 231-41.

TAYLOR, R.C., CULLEN, S.P. and MARTIN, S.J. (2008b). Apoptosis: controlled demolition at the cellular level. Nat Rev Mol Cell Biol 9: 231-241.

TEIXEIRA, J., MAHESWARAN, S. and DONAHOE, P.K. (2001). Mullerian inhibiting substance: an instructive developmental hormone with diagnostic and possible therapeutic applications. Endocr Rev 22: 657-674.

TOLKOVSKY, A.M. (2009). Mitophagy. Biochim Biophys Acta 1793: 1508-1515.

TOLKOVSKY, A.M., XUE, L., FLETCHER, G.C. and BORUTAITE, V. (2002). Mitochondrial disappearance from cells: a clue to the role of autophagy in programmed cell death and disease? Biochimie 84: 233-240.

TONE, S., SUGIMOTO, K., TANDA, K., SUDA, T., UEHIRA, K., KANOUCHI, H., SAMEJIMA, K., MINATOGAWA, Y. and EARNSHAW, W.C. (2007). Three distinct stages of apoptotic nuclear condensation revealed by time-lapse imaging, biochemical and electron microscopy analysis of cell-free apoptosis. Exp Cell Res 313: 3635-3644

TSUJIMOTO, Y. and SHIMIZU, S. (2005). Another way to die: autophagic programmed cell death. Cell Death Differ 12: 1528-1534.

TSUKAMOTO, S., KUMA, A. and MIZUSHIMA, N. (2008a). The role of autophagy during the oocyte-toembryo transition. Autophagy 4: 1076-1078.

TSUKAMOTO, S., KUMA, A., MURAKAMI, M., KISHI, C., YAMAMOTO, A. and MIZUSHIMA, N. (2008b). Autophagy is essential for preimplantation development of mouse embryos. Science 321: 117-120

VANDEN BERGHE, T., LINKERMANN, A., JOUAN-LANHOUET, S., WALCZAK, H. and VANDENABEELE, P. (2014). Regulated necrosis: the expanding network of non-apoptotic cell death pathways. Nat Rev Mol Cell Biol 15: 135-147.

VANDEN BERGHE, T., VANLANGENAKKER, N., PARTHOENS, E., DECKERS, W., DEVOS, M., FESTJENS, N., GUERIN, C.J., BRUNK, U.T., DECLERCQ, W. and VANDENABEELE, P. (2010). Necroptosis, necrosis and secondary necrosis converge on similar cellular disintegration features. Cell Death Differ 17: 922-30.

VAZIRI SANI, F., HALLBERG, K., HARFE, B.D., MCMAHON, A.P., LINDE, A. and GRITLI-LINDE, A. (2005). Fate-mapping of the epithelial seam during palatal fusion rules out epithelial-mesenchymal transformation. Dev Biol 285: 490-495.

VESELSKA, R., ZITTERBART, K., JELINKOVA, S., NERADIL, J. and SVOBODA, A. (2003). Specific cytoskeleton changes during apoptosis accompanying induced differentiation of HL-60 myeloid leukemia cells. Oncol Rep 10: 1049-1058.

VOGT, C. (1842). Untersuchungen uber die Entwicklungsgeschichte der Geburtshelerkroete (Alytes obstetricians). Solothurn: Jent und Gassman. WADA, Y., SUN-WADA, G.H., KAWAMURA, N. and AOYAMA, M. (2014). Role of autophagy in embryogenesis. Curr Opin Genet Dev 27: 60-66.

WEBER, R. (1969). Tissue involution and lysosomal enzymes during anuran metamorphosis. Lysosomes Biol. Pathol. 2: 437-461.

WILSON, C.A. and DAVIES, D.C. (2007). The control of sexual differentiation of the reproductive system and brain. Reproduction 133: 331-359.

WU, J., WILSON, J., HE, J., XIANG, L., SCHUR, P.H. and MOUNTZ, J.D. (1996). Fas ligand mutation in a patient with systemic lupus erythematosus and lymphoproliferative disease. J. Clin. Invest. 98: 1107-1113.

XUE, L., FLETCHER, G.C. and TOLKOVSKY,A.M. (2001). Mitochondria are selectively eliminated from eukaryotic cells after blockade of caspases during apoptosis. Curr Biol 11: 361-365.

YAGINUMA, H., SHIRAIWA, N., SHIMADA, T., NISHIYAMA, K., HONG, J., WANG, S. MOMOI, T., UCHIYAMA, Y. and OPPENHEIM, R.W. (2001). Caspase Activity Is Involved in, but Is Dispensable for, Early Motoneuron Death in the Chick Embryo Cervical Spinal Cord. Molec. Cell Neurosci. 18: 168-182.

YAKOVLEV, A.G., OTA, K., WANG, G., MOVSESYAN, V., BAO, W.-L., YOSHIHARA, K. and FADEN, A.I. (2001). Differential Expression of Apoptotic Protease-Activating Factor-1 and Caspase-3 Genes and Susceptibility to Apoptosis during Brain Development and after Traumatic Brain Injury. J. Neuroscience 21: 7439-7446. 
YUE, Z., JIN, S., YANG, C., LEVINE, A.J. and HEINTZ, N. (2003). Beclin 1, an autophagy gene essential for early embryonic development, is a haploinsufficient tumor suppressor. Proc Natl Acad Sci USA 100: 15077-15082.

ZAKERI, Z., LOCKSHIN, R.A., CRIADO-RODRIGUEZ, L.M. and MARTINEZ, A.C. (2005). A generalized caspase inhibitor disrupts early mammalian development. Int J Dev Biol 49: 43-47.

ZAKERI, Z., QUAGLINO, D. and AHUJA, H.S. (1994). Apoptotic cell death in the mouse limb and its suppression in the hammertoe mutant. Dev Biol 165: 294-297.

ZAKERI, Z.F. and AHUJA, H.S. (1997). Cell deathjapoptosis: normal, chemically induced, and teratogenic effect. Mutat Res 396: 149-161.
ZAKERI, Z.F., QUAGLINO, D., LATHAM, T. and LOCKSHIN, R.A. (1993). Delayed internucleosomal DNA fragmentation in programmed cell death. FASEBJ. 7:470-478

ZAULI, G., VITALE, M., FALCIERI, E., GIBELLINI, D., BASSINI, A., CELEGHINI, C., COLUMBARO, M. and CAPITANI, S. (1997). In vitro Senescence and Apoptotic Cell Death of Human Megakaryocytes. Blood. 90: 2234-2243.

ZUZARTE-LUIS, V. and HURLE, J.M. (2002). Programmed cell death in the developing limb. Int J Dev Biol 46: 871-876. 


\section{Further Related Reading, published previously in the Int. J. Dev. Biol.}

Revisiting DNA damage repair, p53-mediated apoptosis and cisplatin sensitivity in germ cell tumors

Francesca Cavallo, Darren R. Feldman and Marco Barchi

Int. J. Dev. Biol. (2013) 57: 273-280

Causes and consequences of apoptosis in spermatozoa; contributions to infertility and impacts on development

R. John Aitken and Mark A. Baker

Int. J. Dev. Biol. (2013) 57: 265-272

Regulation of programmed cell death during neural induction in the chick embryo Anna Gibson, Neil Robinson, Andrea Streit, Guojun Sheng and Claudio D. Stern Int. J. Dev. Biol. (2011) 55: 33-43

Life-giving caspases: revealing new roles during mouse embryo preimplantation development

Dolores Busso, Calixto Dominguez, Tomas Perez-Acle and Ricardo D. Moreno Int. J. Dev. Biol. (2010) 54: 857-865

Both jnk and apoptosis pathways regulate growth and terminalia rotation during Drosophila genital disc development

Sergio Benitez, Claudia Sosa, Nicolás Tomasini and Ana Macías

Int. J. Dev. Biol. (2010) 54: 643-653

Mpl receptor defect leads to earlier appearance of hematopoietic cells/hematopoietic stem cells in the Aorta-Gonad-Mesonephros region, with increased apoptosis Maud Fleury, Laurence Petit-Cocault, Denis Clay and Michèle Souyri Int. J. Dev. Biol. (2010) 54: 1067-1074

Apoptosis in Drosophila: compensatory proliferation and undead cells Francisco A. Martín, Ainhoa Peréz-Garijo and Ginés Morata Int. J. Dev. Biol. (2009) 53: 1341-1347

Key apoptosis regulating proteins are down-regulated during postnatal tissue development

Shane D. Madden, Maryanne Donovan and Thomas G. Cotter

Int. J. Dev. Biol. (2007) 51: 415-424

5 yr ISI Impact Factor $(2013)=2.879$
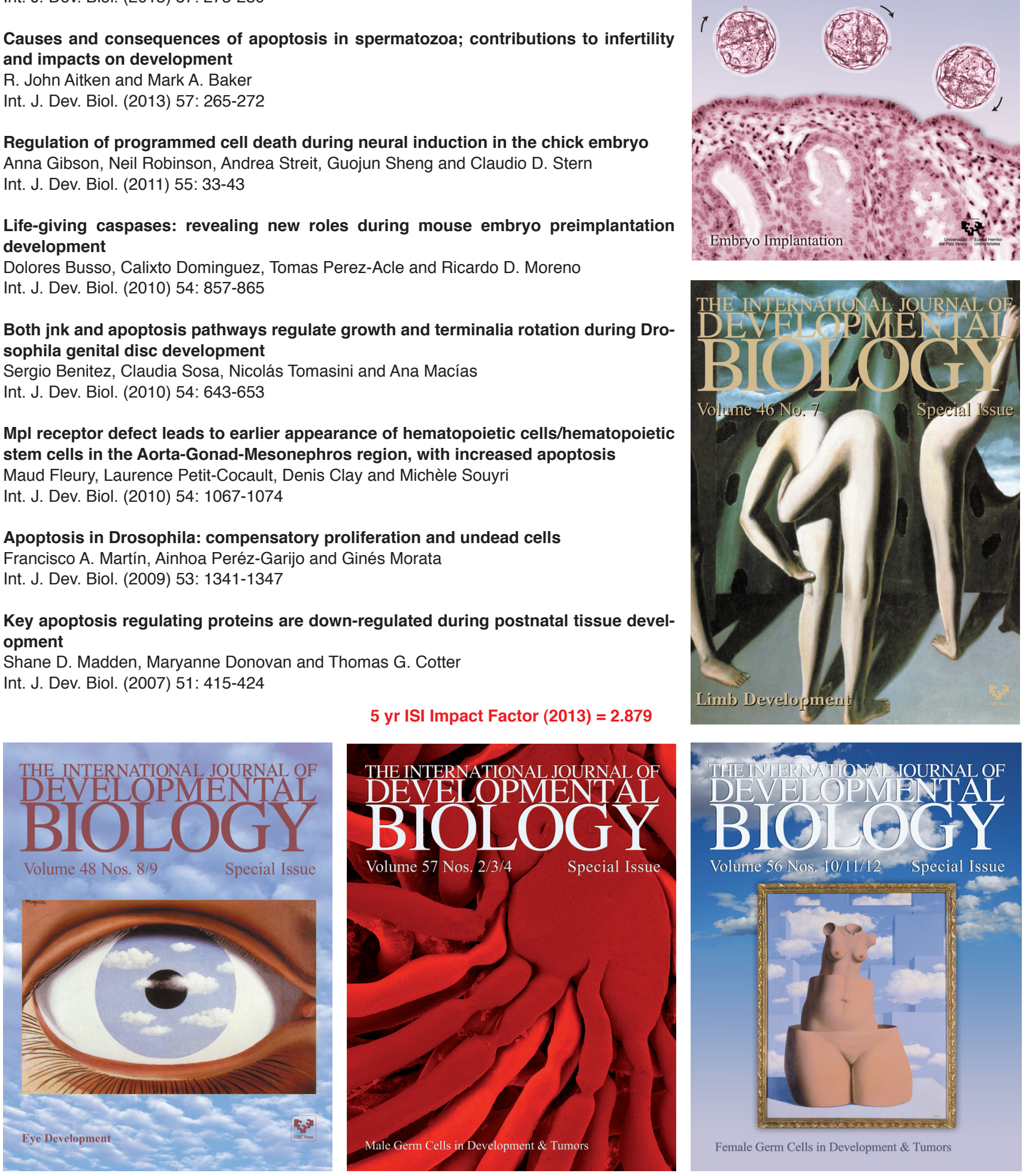